\title{
$\alpha$-Tocopherol enhances tumour growth inhibition by cis-dichlorodiammine platinum (II)
}

S. Sarna, A. Kumar and R.K. Bhola

\author{
Department of Zoology, Gauhati University, Guwahati, India
}

\begin{abstract}
Correspondence

S. Sarna

Department of Zoology

Gauhati University

Guwahati 781014

India

S. Sarna is the recipient of financial assistance in the form of a research associateship from the University Grants Commission, New Delhi, India.

Received October 27, 1998 Accepted April 10, 2000

Present studies indicate that $\alpha$-tocopherol enhances the efficacy of cisplatin as demonstrated by inoculation of Dalton's lymphoma cells incubated with either cisplatin $(5$ or $10 \mu \mathrm{g} / \mathrm{ml})$ alone or cisplatin $+\alpha-$ tocopherol ( 25 or $50 \mu \mathrm{g} / \mathrm{ml})$ into $\mathrm{C} 3 \mathrm{H} / \mathrm{He}$ mice. Tumour cells $\left(3 \times 10^{6}\right.$ cells/mouse) incubated with cisplatin grow slowly in syngeneic mice as indicated by the late appearance of tumour. However, mice failed to develop tumour when inoculated with tumour cells incubated with cisplatin $+\alpha$-tocopherol. When the animals were challenged with tumour cells $\left(3 \times 10^{6}\right.$ cells/mouse) on the 15 th day after the initial inoculation, $30-50 \%$ survived more than 60 days, with $10 \%$ tumourfree survivors being observed in some groups. Antitumour activity was higher in mice receiving lymphoma cells $\left(3 \times 10^{6}\right.$ cells/mouse $)$ preincubated with cisplatin $+\alpha$-tocopherol compared to cisplatin alone. Tumour-bearing mice receiving cisplatin in combination with different concentrations of $\alpha$-tocopherol exhibited significantly higher $(\mathrm{P}<0.001)$ intratumour platinum content $(123-306 \%)$ but without any change in the kidney platinum content as compared to those receiving cisplatin ( 5 or $10 \mu \mathrm{g} / \mathrm{ml}$ ) alone. Enhancement of cisplatin-induced tumour growth inhibition is probably due to the modulation of tumour cell membrane permeability by $\alpha$-tocopherol. $\alpha$-Tocopherol might increase the influx of cisplatin into tumour cells, causing the DNA repair machinery to be less efficient due to increased efficiency of adduct formation in the DNA molecule. This effect of $\alpha$-tocopherol can render cisplatin more effective as an antitumour agent.
\end{abstract}

Key words

- Cisplatin

- Vitamin E

- Dalton's lymphoma

- Tumour growth inhibition

\section{Introduction}

Cisplatin has been used as an immunotherapeutic agent against tumours and has been reported to affect tumour cell antigenicity in vitro (1-4). Various cytotoxic agents have been used in combination with cisplatin to enhance its antitumour effect (5-10). Like other different combinations, thermochemotherapy with cisplatin or carboplatin has also been tried and both combinations were reported to be superior to treatment with hyperthermia alone (11). Preheating of cells also enhanced the cytotoxic effect of cisplatin administered shortly after heating (12). The cytotoxic effect of cisplatin combined with liposomal valinomycin on human ovarian tumour cells has been reported (13). Studies on the pharmacological effect of cisplatin combined with peplomycin have shown a strong block of the $\mathrm{G}_{2} \mathrm{M}$ phase of the cell cycle resulting in the most effective killing of tumour cells (14). Clinical trials with this combination therapy have proved its usefulness for improving the clinical condition of the patients (14). 
In addition to acting as an antitumour agent, $\alpha$-tocopherol has been reported to be effective in the inhibition of spontaneous, $X$ ray and chemically induced transformation of tumour cells (15-17) and to induce morphological differentiation and growth inhibition of murine and human neuroblastoma cells in culture (18). $\alpha$-Tocopherol has also been reported to induce apoptosis in erythroid leukemia and in prostate and breast cancer cells (19). An additive or synergistic effect of $\alpha$-tocopherol with a few antitumour agents has been reported for murine neuroblastoma cells both in vitro (20) and in vivo (21). Similarly, some cytotoxic chemotherapeutic agents have also been used in combination with cisplatin in an attempt to achieve enhanced antitumour effects against cisplatinresistant tumours $(7,22)$. Some success has been achieved but many tumour types are poorly responsive to therapy with cisplatin alone or in combination with other chemotherapeutic agents (23). Hence a lymphoma was chosen to study the synergistic effect of cisplatin and $\alpha$-tocopherol. In the present investigation, we studied the tumour growth pattern of Dalton's lymphoma cells in vivo after incubation in vitro with different combinations of cisplatin and $\alpha$-tocopherol to determine whether $\alpha$-tocopherol enhances the antitumour effect of a low dose of cisplatin.

\section{Material and Methods}

Male and female mice of the $\mathrm{C} 3 \mathrm{H} / \mathrm{He}$ strain aged 8-10 weeks and weighing 20-22 $\mathrm{g}$ were used in all experiments. Mice received a commercial feed (Goldmohar, Lipton, India) and water ad libitum. Animals were kept under standard conditions (in a pathogen-free environment at $22-23^{\circ} \mathrm{C}$, with $65-70 \%$ relative humidity.

Dalton's lymphoma was obtained from the Chittaranjan Cancer Research Center, Calcutta, India, and maintained in the laboratory by regular serial transplantations in inbred $\mathrm{C} 3 \mathrm{H} / \mathrm{He}$ mice after a regular interval of 12 days.

Cisplatin was a generous gift from Bristol Myers Co., Syracuse, NY, USA. Dulbecco's modified Eagle's medium (DMEM) and glutamine were purchased from Hi-Media, Mumbai, India. Fetal bovine serum (FBS), $\alpha$-tocopherol, penicillin and streptomycin were purchased from Sigma Chemical Co., St. Louis, MO, USA. All other chemicals were purchased locally and were of analytical grade or equivalent.

Dalton's lymphoma cells were grown in DMEM supplemented with $10 \%$ FBS, $0.3 \%$ glutamine, $10 \mathrm{mM} \mathrm{NaHCO}_{3}$, and $1 \%$ penicillin (50 units $/ \mathrm{ml})$-streptomycin $(50 \mu \mathrm{g} / \mathrm{ml})$ on culture dishes in a humidified atmosphere of $5 \% \mathrm{CO}_{2}$ at $37 \pm 1{ }^{\circ} \mathrm{C}$. The $\mathrm{pH}$ was maintained at 7.2-7.4 by regulating the flow of $\mathrm{CO}_{2}$-air.

Asynchronized lymphoma cells were treated in vitro with cisplatin and $\alpha$-tocopherol before being injected into different groups of mice. Tumour cells were brought to a concentration of $3 \times 10^{6}$ cells $/ \mathrm{ml}$ in DMEM containing $10 \%$ FBS, antibiotics and sodium bicarbonate. Tumour cell suspensions were incubated for $1 \mathrm{~h}$ at $37^{\circ} \mathrm{C}$ with different concentrations of cisplatin alone, $\alpha$-tocopherol alone, or a combination of both. The following groups were used: 1) control, 2) $\mathrm{DMSO}$, 3) $25 \mu \mathrm{g} / \mathrm{ml} \alpha$-tocopherol, 4) 50 $\mu \mathrm{g} / \mathrm{ml} \alpha$-tocopherol, 5) $5 \mu \mathrm{g} / \mathrm{ml}$ cisplatin, 6) $10 \mu \mathrm{g} / \mathrm{ml}$ cisplatin, 7) $5 \mu \mathrm{g} / \mathrm{ml}$ cisplatin +25 $\mu \mathrm{g} / \mathrm{ml} \alpha$-tocopherol, 8) $5 \mu \mathrm{g} / \mathrm{ml}$ cisplatin + $50 \mu \mathrm{g} / \mathrm{ml} \alpha$-tocopherol, 9) $10 \mu \mathrm{g} / \mathrm{ml}$ cisplatin $+25 \mu \mathrm{g} / \mathrm{ml} \alpha$-tocopherol, and 10) $10 \mu \mathrm{g} / \mathrm{ml}$ cisplatin $+50 \mu \mathrm{g} / \mathrm{ml} \alpha$-tocopherol. Viability of tumour cells was determined by the Trypan blue exclusion test. Tumour cell suspensions always exhibited more than $90 \%$ viability before incubation with any compound. Tumour cells incubated with different doses of cisplatin exhibited more than $80 \%$ viable cells, whereas in the case of $\alpha$-tocopherol, viability was found to be $80-90 \%$. After incubation, $3 \times 10^{6}$ viable cells were injected 
ip into different groups of mice. Groups of mice in which the tumour did not appear were challenged with tumour cells $\left(3 \times 10^{6}\right.$ cells/mouse) on day 15 th after the initial inoculation. Increased survival time, percent survivors on different days and percent of tumour-free survivors were determined in control and experimental groups. Percent increase in the life span (\%ILS) of the experimental groups was calculated using the following formula: \%ILS $=[(\mathrm{T}-\mathrm{C}) / \mathrm{C}] \times 100$, where $\mathrm{T}=$ mean survival days of treated mice and $\mathrm{C}=$ mean survival days of untreated control mice.

For estimation of platinum content in tumour and kidney, freshly prepared cisplatin or cisplatin $+\alpha$-tocopherol solutions were injected ip into tumour-bearing mice. After $24 \mathrm{~h}$ mice were sacrificed, lymphoma cells were collected, counted with an electronic cell counter and washed with DMEM twice. The kidneys were removed at the same time and washed with DMEM twice. Tissues were digested with hot nitric acid to remove most of the organic matter and diluted 10 -fold in $1 \% \mathrm{HCl}$ to keep the concentration of salts below $0.2 \%$. Platinum content was estimated with the VG plasmasquad PQ1 ICPMS apparatus. The analytical procedure completely disrupted the platinum molecule and no information was obtained about the chemical form of platinum in tissues.

Each experimental and control group consisted of 10 mice. Each set of experiment was repeated thrice and the results are reported as arithmetic mean \pm SD. Statistical significance was analyzed by the Student $t$ test.

\section{Results}

The solvent (DMSO) failed to show any effect on tumour growth inhibition since the survival time of the control animals was not significantly different from that of animals inoculated with tumour cells treated with DMSO alone. All animals inoculated with
Dalton's lymphoma cells incubated with different concentrations of $\alpha$-tocopherol developed tumours. As compared to control, no significant difference in the mean survival time of mice was observed in the group inoculated with tumour cells incubated with $25 \mu \mathrm{g} / \mathrm{ml} \alpha$-tocopherol (Table 1). However, when the concentration of $\alpha$-tocopherol was increased to $50 \mu \mathrm{g} / \mathrm{ml}, 10 \%$ of the animals exhibited an increase in mean survival time of 20 days. The $\%$ ILS with 25 and $50 \mu \mathrm{g} / \mathrm{ml}$ $\alpha$-tocopherol was 7 and 17 , respectively (Table 1).

Mice receiving tumour cells incubated with cisplatin ( 5 or $10 \mu \mathrm{g} / \mathrm{ml}$ ) exhibited a significant increase in mean survival time compared to control (Table 1). High concentration $(10 \mu \mathrm{g} / \mathrm{ml})$ resulted in $75 \% 60$-day survivors with a $228 \%$ increase in life span without any tumour-free survivor. However, with $5 \mu \mathrm{g} / \mathrm{ml}$, the increase in life span and 60 -day survivors decreased to 141 and $17 \%$, respectively. Animals initially inoculated with tumour cells incubated with $10 \mu \mathrm{g} / \mathrm{ml}$ cisplatin and subsequently challenged exhibited a $142 \%$ increase in life span with $12 \%$ tumour-free survivors (Table 2 ).

Mice failed to develop tumours when inoculated with tumour cells incubated with 5 or $10 \mu \mathrm{g} / \mathrm{ml}$ cisplatin along with different

Table 1 - Increased mean survival time and percent increased life span after inoculating tumour cells incubated with cisplatin and/or $\alpha$-tocopherol.

alncluding 60-day survivors; $\mathrm{b}[(\mathrm{T}-\mathrm{C}) / \mathrm{C}] \times 100$, where $\mathrm{T}=$ mean survival days of treated mice and $\mathrm{C}=$ mean survival days of untreated control mice; cthree groups each consisting of 10 mice; P vs control (Student t-test). NS, Nonsignificant.

\begin{tabular}{lccccc}
\hline Treatment & $\begin{array}{c}\text { Mean } \\
\text { survival } \\
\text { time in } \\
\text { days } \pm \text { SD }^{a}\end{array}$ & $\begin{array}{c}\text { \% Increased } \\
\text { life span } \\
\text { of tumour- } \\
\text { bearing } \\
\text { mice }\end{array}$ & $\begin{array}{c}\text { \% 60/more } \\
\text { than 60-day } \\
\text { tumour- } \\
\text { bearing } \\
\text { survivors }\end{array}$ & $\begin{array}{c}\% \\
\text { Tumour- } \\
\text { free } \\
\text { survivors }\end{array}$ & P \\
\hline None & $18.8 \pm 2.4$ & - & - & - & \\
DMSO & $19.3 \pm 2.7$ & 3 & - & - & NS \\
$\alpha$-Tocopherol $(25 \mu \mathrm{g} / \mathrm{ml})$ & $20.2 \pm 1.9$ & 7 & - & - & $\mathrm{NS}$ \\
$\alpha$-Tocopherol $(50 \mu \mathrm{g} / \mathrm{ml})$ & $22.0 \pm 3.2$ & 17 & - & - & $<0.05$ \\
Cisplatin $(5 \mu \mathrm{g} / \mathrm{ml})$ & $45.3 \pm 3.5$ & 141 & 17 & - & $<0.001$ \\
Cisplatin $(10 \mu \mathrm{g} / \mathrm{ml})$ & $61.7 \pm 4.8$ & 228 & 75 & - & $<0.001$
\end{tabular}


concentrations of $\alpha$-tocopherol. These animals when challenged on day 15 th after the initial inoculation exhibited a $174 \%$ increase in life span with $30 \% 60$-day survivors in the group receiving tumour cells incubated with $5 \mu \mathrm{g} / \mathrm{ml}$ cisplatin $+25 \mu \mathrm{g} / \mathrm{ml} \alpha$-tocopherol (Table 2). The increase in the life span of the animals was found to be $170 \%$ with $40 \% 60$ day survivors if the dose of $\alpha$-tocopherol was increased to $50 \mu \mathrm{g} / \mathrm{ml}$ in combination with cisplatin. This combination also resulted into $10 \%$ tumour-free survivors. Similarly, the group of mice initially receiving tumour cells incubated with $10 \mu \mathrm{g} / \mathrm{ml}$ cisplatin $+25 \mu \mathrm{g} / \mathrm{ml} \alpha$-tocopherol when challenged on the same day resulted into a $181 \%$ increase in life span with 38\% 60-day survi- vors. The increase in life span was found to be $203 \%$ including $50 \%$ 60-day survivors when the concentration of $\alpha$-tocopherol was increased to $50 \mu \mathrm{g} / \mathrm{ml}$ in combination with cisplatin (Table 2).

The effect of $\alpha$-tocopherol on in vivo incorporation of cisplatin into tumour and kidney is shown in Table 3. There was a direct correlation between the concentration of cisplatin administered and platinum content in tumour and kidney. $\alpha$-Tocopherol significantly enhanced the intratumour platinum content. When cisplatin was combined with 20 or $40 \mathrm{mg} / \mathrm{kg} \alpha$-tocopherol, a 256 and $306 \%$ increase in the intratumour platinum content was recorded, respectively. However, when the concentration of $\alpha$-tocopherol

Table 2 - Increased mean survival time, percent increase in the life span and tumour-free survivors after challenge in different groups immunized with cisplatin or cisplatin $+\alpha$-tocopherol-incubated tumour cells.

alncluding 60-day survivors; $\mathrm{b}[(\mathrm{T}-\mathrm{C}) / \mathrm{C}] \times 100$, where $\mathrm{T}=$ mean survival days of treated mice and $\mathrm{C}=$ mean survival days of untreated control mice; Cthree groups each consisting of 10 mice; P vs control (Student t-test).

\begin{tabular}{|c|c|c|c|c|c|}
\hline Treatment & $\begin{array}{c}\text { Mean } \\
\text { survival } \\
\text { time in } \\
\text { days } \pm \mathrm{SD}^{\mathrm{a}}\end{array}$ & $\begin{array}{l}\text { \% Increased } \\
\text { life span } \\
\text { of tumour- } \\
\text { bearing } \\
\text { mice }^{b}\end{array}$ & $\begin{array}{c}\% 60 / \text { more } \\
\text { than } 60 \text {-day } \\
\text { tumour- } \\
\text { bearing } \\
\text { survivorsc }\end{array}$ & $\begin{array}{c}\% \\
\text { Tumour- } \\
\text { free } \\
\text { survivorsc }\end{array}$ & $P$ \\
\hline None & $18.8 \pm 2.4$ & - & - & - & \\
\hline Cisplatin $(10 \mu \mathrm{g} / \mathrm{ml})$ & $45.6 \pm 4.2$ & 143 & - & 12.5 & $<0.001$ \\
\hline Cisplatin $(5 \mu \mathrm{g} / \mathrm{ml})+\alpha$-tocopherol $(25 \mu \mathrm{g} / \mathrm{ml})$ & $51.5 \pm 5.8$ & 174 & 30 & - & $<0.001$ \\
\hline Cisplatin $(5 \mu \mathrm{g} / \mathrm{ml})+\alpha$-tocopherol $(50 \mu \mathrm{g} / \mathrm{ml})$ & $50.8 \pm 6.3$ & 170 & 40 & 10 & $<0.001$ \\
\hline Cisplatin $(10 \mu \mathrm{g} / \mathrm{ml})+\alpha$-tocopherol $(25 \mu \mathrm{g} / \mathrm{ml})$ & $52.4 \pm 5.7$ & 181 & 38 & - & $<0.001$ \\
\hline Cisplatin $(10 \mu \mathrm{g} / \mathrm{ml})+\alpha$-tocopherol $(50 \mu \mathrm{g} / \mathrm{ml})$ & $57.0 \pm 7.4$ & 203 & 50 & - & $<0.001$ \\
\hline
\end{tabular}

Table 3 - Platinum content in kidney and tumour after treatment with cisplatin alone or in combination with $\alpha$ tocopherol.

*P $<0.001$ vs $3 \mathrm{mg} / \mathrm{kg}$ cisplatin (Student t-test). **Nonsignificant vs $3 \mathrm{mg} / \mathrm{kg}$ cisplatin. Figures in parentheses indicate the percent increase in intratumour platinum content after treatment with cisplatin $+\alpha$-tocopherol.

\begin{tabular}{lcc}
\hline Treatment & \multicolumn{2}{c}{ Platinum content $(\mu \mathrm{g} / \mathrm{g}$ wet tissue $)$} \\
\cline { 2 - 3 } & \multicolumn{1}{c}{ Tumour } & Kidney \\
\hline $3 \mathrm{mg} / \mathrm{kg}$ cisplatin & $0.80 \pm 0.05$ & $6.28 \pm 1.37$ \\
$9 \mathrm{mg} / \mathrm{kg}$ cisplatin & $3.82 \pm 0.18^{*}(377 \%)$ & $12.98 \pm 2.67 *$ \\
$3 \mathrm{mg} / \mathrm{kg}$ cisplatin $+20 \mathrm{mg} / \mathrm{kg} \alpha$-tocopherol & $2.85 \pm 0.52^{*}(256 \%)$ & $6.67 \pm 1.90^{* *}$ \\
$3 \mathrm{mg} / \mathrm{kg}$ cisplatin $+40 \mathrm{mg} / \mathrm{kg} \alpha$-tocopherol & $3.25 \pm 0.46^{*}(306 \%)$ & $6.95 \pm 1.22^{* *}$ \\
$3 \mathrm{mg} / \mathrm{kg}$ cisplatin $+60 \mathrm{mg} / \mathrm{kg}$ pms-tocopherol & $1.79 \pm 0.60^{*}(123 \%)$ & $6.65 \pm 1.50^{* *}$
\end{tabular}


was enhanced to $60 \mathrm{mg} / \mathrm{kg}$, the increase in platinum content was reduced to $123 \%$. $\alpha$ Tocopherol failed to show any effect on the platinum content of the kidney.

\section{Discussion}

Vitamins are antioxidants since they prevent the toxic effects of free radicals, which can interact with a variety of cellular molecules causing inhibition or alteration of functions through lipid peroxidation, DNA damage and enzyme inactivation. Vitamins possess chemical properties that allow them to regulate the oxidation-reduction potential of the cell and are frequently used in cancer therapies (24).

The present study indicates that $\alpha$-tocopherol enhances the tumour growth inhibition induced by a low dose of cisplatin. $\alpha$ Tocopherol alone had no significant effect on tumour growth inhibition, with only $10 \%$ of the animals showing increased survival time when inoculated with tumour cells incubated with $50 \mu \mathrm{g} / \mathrm{ml} \alpha$-tocopherol. It has been reported that $\alpha$-tocopherol slightly enhances the proliferation (25) and inhibits the differentiation (26) of mouse myeloid leukemia cells. The growth of a variety of cell types is inhibited by vitamin E succinate (27$29)$ whereas $d-\alpha$-tocopherol or its analogues such as acetate and nicotinate esters as well as the water-soluble analogue Trolox had very little effect on cell growth and differentiation in vitro (27). It has been suggested that vitamin E succinate, having a negative charge, membrane permeability and stability in intracellular compartments, inhibits cell growth and transformation, at least in part due to the inhibition of protein kinase $\mathrm{C}$ activity. However, vitamin E succinate did not significantly affect the growth of melanoma cells in culture (24).

Mice inoculated with cisplatin incubated with tumour cells exhibited a significant increase in their mean survival time compared to control. Palpable tumour was observed on day 15 in the group receiving tumour cells incubated with $5 \mu \mathrm{g} / \mathrm{ml}$ cisplatin, but when the concentration of cisplatin was enhanced to $10 \mu \mathrm{g} / \mathrm{ml}$, tumour failed to appear on the same day. Even a challenge of the latter group with tumour cells resulted into an increase in the mean survival time of mice compared to control with $12 \%$ tumour-free survivors (Table 2). This shows that cisplatin brings about some changes in lymphoma cells responsible for the late appearance of the tumour. These changes may be morphological involving loss of membrane integrity and cell shrinkage (30,31). Cell surface and biochemical alterations have been reported to occur when fibrosarcoma cells are treated in vitro with cisplatin $(3,32)$. In the present system a greater therapeutic benefit was achieved with $10 \mu \mathrm{g} / \mathrm{ml}$ cisplatin which resulted into increased mean survival time of animals even after the challenge. This concentration of cisplatin was shown to release a maximum amount of sialic acid from tumour cells if incubated in vitro (32) and may have been responsible for this effect. A synergistic effect of cisplatin and $\alpha$-tocopherol was also apparent in the present study. The therapeutic potential of cisplatin was greatly enhanced by $\alpha$-tocopherol since tumour cells incubated with various combinations of cisplatin $+\alpha$-tocopherol failed to grow in animals. The mean survival time of animals increased even after challenge in different combination groups. This shows that tumour cells are viable after $1 \mathrm{~h}$ of drug treatment, being able to enhance the immune response but unable to grow into a tumour. Recently, it has been reported that after treatment with cisplatin and $\alpha$-tocopherol these tumour cells progress towards necrosis (33). A marked inhibition of tumour growth was reported earlier when cisplatin was directly inoculated into tumour-bearing mice in combination with vitamins $(24,34)$.

Therapeutic effect of different doses of cisplatin is directly related to the intratumour platinum content. In the present study, a 
subtherapeutical dose of cisplatin $(3 \mathrm{mg} / \mathrm{kg})$ was used in combination with $\alpha$-tocopherol in order to elevate the intratumour platinum content as well as to observe its nephrotoxic effect. The present study suggests that one of the causes of enhancement of cisplatin-induced tumour growth inhibition by $\alpha$-tocopherol might increase the uptake of cisplatin into tumour cells. This process is specific because platinum content was elevated only in the tumour and not in the kidney of the animals receiving $\alpha$-tocopherol along with cisplatin. The increased uptake of cisplatin by $\alpha$-tocopherol is suggested to be the result of the modulation of cell membrane permeability altering the level of peroxidation (18). In addition, membrane electropermeabilisation also affects both influx and efflux of cisplatin from tumour cells (35). The influx of some anticancer agents has been reported to be increased by vitamin A, which inhibits the growth of neuroblastoma cells (36-39). In addition to the effect of cisplatin on cell permeability, DNA is the critical target for cisplatin-induced cytotoxicity (40). The mechanism involved in the action of cisplatin is its ability to form covalent adducts with the genomic molecules (41-44). This process renders the cells incapable of replication, with consequent cell death (40). Cisplatin has been reported to induce programmed cell death or apoptosis that is triggered by the presence of cisplatin-DNA adducts; however, the signal transduction mechanism that links DNA damage to the cell death pathway remains unknown (30). $\alpha$ Tocopherol may also act at the site of DNA and RNA where cisplatin binds (45), possibly increasing the efficiency of adduct for- mation in the genome, thus decreasing the ability of cells to remove these adducts. Such a decrease in the efficiency of the DNA repair machinery of tumour cells enables cisplatin to be more effective as an antitumour agent. Another possibility is that vitamins exert antineoplastic effects by increasing cytolytic and autophagic activity, cell membrane disruption and increased collagen synthesis, thus inhibiting the cancer cell metabolism and proliferation (46) or by stimulating antitumour immunity. Stimulation of helper $\mathrm{T}$ cells might enhance the antitumour activity of cisplatin (21). $\alpha$-Tocopherol has been reported to enhance both lymphoproliferative reactions and the antitumour effect of adriamycin $(47,48)$.

The present results indicate that combined treatment of Dalton's lymphoma with cisplatin and $\alpha$-tocopherol has some advantage over cisplatin alone. The enhancement of tumour growth inhibition by $\alpha$-tocopherol is possibly due to its effects on the influx of cisplatin into tumour cells, increasing the efficiency of adduct formation in genomic DNA and thus weakening the DNA repair machinery of tumour cells. This effect of $\alpha$ tocopherol renders cisplatin more effective as an antitumour agent and indicates the importance and function of vitamins in cancer therapy.

\section{Acknowledgments}

We are thankful to Dr. D.T. Khating, Head, Regional Sophisticated Instrumentation Centre, Shillong, for providing the facilities for platinum measurement.

\section{References}

1. Bahadur A, Sarna S \& Sodhi A (1984). Enhanced cell mediated immunity in mice after cisplatin treatment. Polish J oumal of Pharmacology and Pharmacy, 36: 441448.

2. Gan XH, J ewett A \& Bonavida B (1992).
Activation of human peripheral blood derived monocytes by cis-diamminedichloroplatinum: enhanced tumoricidal activity and secretion of tumour necrosis factoralpha. Natural Immunity, 11: 144-155.

3. Sarna S \& Sodhi A (1978). Chemoimmu- notherapeutical study on a fibrosarcoma with cis-dichlorodiammine platinum (II). Indian J ournal of Experimental Biology, 16: 1236-1239.

4. Sarna S, Sodhi A \& Bhola RK (1989). A possible mechanism of tumour regression 
in cisplatin treated mice. Polish J ournal of Pharmacology and Pharmacy, 41: 69-76.

5. Chen G \& Pan Q (1988). Potentiation of antitumour activity of cisplatin in mice by 3-aminobenzamide and nicotinamide. Cancer Chemotherapy and Pharmacology, 22: 303-307.

6. Ohkawa K, Tsukada Y, Dohzono H, Koike $K \&$ Terashima Y (1988). The effects of coadministration of selenium and cisplatin (CDDP) on CDDP-induced toxicity and antitumor activity. British J ournal of Cancer, 58: 38-41.

7. Onoda J M, Nelson KK, Taylor J D \& Honn KV (1988). Cisplatin and nifedipine: synergistic antitumor effect against an inherently cisplatin-resistant tumor. Cancer Letters, 40: 39-47.

8. Quarless SA (1988). Chloroquine enhances the cytotoxicity of cis-diamminedichloroplatinum II. Cancer Biochemistry and Biophysics, 10: 11-15.

9. Sarna S \& Bhola RK (1989). Combination therapy of transplantable tumour in mice with cisplatin and glucose. Current Science, 58: 231-233.

10. Sarna S \& Bhola RK (1993). Chemoimmunotherapeutical study on Dalton's lymphoma in mice using cisplatin and ascorbic acid: synergistic antitumour effect in vivo and in vitro. Archivum Immunologiae et Therapiae Experimentalis, 41: 327-333.

11. Schem BC, Mella O \& Dahl O (1992). Thermochemotherapy with cisplatin and carboplatin in the $\mathrm{BT}^{4}$ rat glioma in vitro and in vivo. International J ournal of Radiation Oncology, Biology, Physics, 23: 109114.

12. Majima H, Kashiwado K, Egawa S, Suzuki N \& Urano M (1992). Interaction between the kinetics of thermotolerance and effect of cis-diamminedichloroplatinum (II) or bleomycin given at $37^{\circ}$ or $43^{\circ} \mathrm{C}$. International J ournal of Hyperthermia, 8: 431442.

13. Daoud SS \& Forde NH (1991). Synergistic cytotoxic action of cisplatin and liposomal valinomycin on human ovarian carcinoma cells. Cancer Chemotherapy and Pharmacology, 28: 371-376.

14. Kawamoto K, Wada $\mathrm{Y}$, Kumazawa $\mathrm{H}$, Yamashita T, Kumazawa T \& Matsumura $\mathrm{H}$ (1992). Experimental and clinical evaluation by flow cytometry for the mechanism of combination therapy (cisplatin and paplomycin). Cytometry, 13: 307-313.

15. Borek C, Ong A, Mason H, Donahue L \& Biaglow JE (1986). Selenium and vitamin $E$ inhibit radiogenic and chemically induced transformation in vitro via different mechanisms. Proceedings of the National
Academy of Sciences, USA, 83: 14901494.

16. Radner BS \& Kennedy AR (1986). Suppression of X-ray induced transformation by vitamin $\mathrm{E}$ in mouse $\mathrm{C} 3 \mathrm{H} 10 \mathrm{~T} 1 / 2$ cells. Cancer Letters, 32: 25-32.

17. Yano $\mathrm{T}$, Obata $\mathrm{Y}$, Yano $\mathrm{Y}$, Otani $\mathrm{S} \&$ Ichikawa T (1994). Vitamin E acts as a useful chemopreventive agent to reduce spontaneous lung tumorigenesis in mice. Cancer Letters, 87: 205-210.

18. Prasad KN \& Rama B (1984). Modification of the effect of the pharmacological agents, ionizing radiation and hyperthermia on tumour cells by vitamin E. In: Prasad KN (Editor), Vitamins, Nutrition and Cancer. Karger, Basel.

19. Sigounas $G$, Anagnostou $A \&$ Steiner $M$ (1997). dl- $\alpha$-tocopherol induces apoptosis in erythroleukemia, prostate, and breast cancer cells. Nutrition and Cancer, 28: 3035.

20. Prasad KN, Prasad EJ \& Ramanujam S (1980). Vitamin E increases the growth inhibitory and differentiating effect of tumor therapeutic agent on neuroblastoma and glioma cells in culture. Proceedings of Experimental Biology and Medicine, 164: 158-164.

21. Sue K, Nakagawara A, Okuzone S, Fukushige T \& Ikeda K (1988). Combined effect of vitamin $E$ ( $\alpha$-tocopherol) and cisplatin on the growth of murine neuroblastoma in vivo. European J ournal of Cancer and Clinical Oncology, 24: 1751-1758.

22. Liepman MK, Wheeler RW, Zuckerman KS \& Lobuglio AF (1982). Combination chemotherapy of refractory lymphoma with cis-dichlorodiamineplatinum, vinblastine, and bleomycin. Cancer, 50: 27362739.

23. Aamdal S, Fodstad O \& Pihl A (1988). Sodium thiosulfate fails to increase the therapeutic index of intravenously administered cis-diamminedichloroplatinum (II) in mice bearing murine and human tumors. Cancer Chemotherapy and Pharmacology, 21: 129-133.

24. Prasad KN (1995). Vitamins induce cell differentiation, growth inhibition and enhance the effect of tumor therapeutic agents on some cancer cells in vitro. In: Prasad KN, Santamaria L \& Williams RM (Editors), Nutrients in Cancer Prevention and Treatment. Humana Press, New J ersey, USA.

25. Sakagami H, Asaka K, Abe E, M iyamura C, Suda T \& Konno K (1981). Effect of dl-atocopherol (vitamin E) on the differentiation of mouse myeloid leukemia cells. J ournal of Nutritional Science and Vitami- nology, 27: 291-300.

26. Takenaga K, Honma Y \& Hozumi M (1981). Inhibition of differentiation of mouse myeloid leukemia cells by phenolic antioxidants and $\alpha$-tocopherol. Gann, 72: 104112.

27. Kline K \& Sanders BG (1990). Antitumor proliferation properties of vitamin $\mathrm{E}$. In: J acobs MM (Editor), Vitamins and Minerals in the Prevention and Treatment of Cancer. CRC Press, Boca Raton, FL, USA.

28. Kline K, Cochran GS \& Sanders BG (1990). Growth inhibitory effects of vitamin E succinate on retrovirus transformed tumor cells in vitro. Nutrition and Cancer, 14: 2731.

29. Gopalakrishna R, Gundimeda U \& Chen Z (1995). Vitamin E succinate inhibits protein kinase C: correlation with its unique inhibitory effects on cell growth and transformation. In: Prasad KN, Santamaria L \& Williams RA (Editors), Nutrients in Cancer Prevention and Treatment. Humana Press, New J ersey, USA.

30. Chu G (1994). Cellular responses to cisplatin: the roles of DNA binding proteins and DNA repairs. J ournal of Biological Chemistry, 269: 787-790.

31. Yonezawa M, Otsuka T, Matsui N, Tsuji H, Kato KH, Moriyama A \& Kato T (1996). Hyperthermia induces apoptosis in malignant fibrous histiocytoma cells in vitro. International J ournal of Cancer, 66: 347351.

32. Sama S, Bhola RK \& Sodhi A (1988). Release of protein bound sialic acid from fibrosarcoma cells after cis-dichlorodiammine platinum (II) treatment: the possible role in tumor regression. Polish J ournal of Pharmacology and Pharmacy, 40: 295-302.

33. Sarna S, Bhola RK \& Kumar A (1998). Cytological changes in ascites Dalton's lymphoma in mice after treatment with cis-dichlorodiammine platinum (II) and $\alpha$ tocopherol. Medical Science Research, 26: 603-606.

34. Sarna S, Kumar A \& Bhola RK (1996). Combined effect of cisplatin and $\alpha$-tocopherol on mice bearing Dalton's lymphoma. Current Science, 70: 1022-1025.

35. Melvik JE, Dornish J M \& Pettersen EO (1992). The binding of cis-dichlorodiammineplatinum (II) to extracellular and intracellular compounds in relation to drug uptake and cytotoxicity in vitro. British J ournal of Cancer, 66: 260-265.

36. Chapman SK (1980). Antitumor effects of vitamin $\mathrm{A}$ and inhibitors of omithine decarboxylase in cultured neuroblastoma and glioma cells. Life Sciences, 26: 1359- 
1366.

37. Helson L \& Helson C (1985). Human neuroblastoma cells and 13-cis-retinoic acid. J ournal of Neuro-Oncology, 3: 39-41.

38. Komiyama S, Hiroto T \& Ryu S (1978). Synergistic combination therapy of 5-fluorouracil, vitamin A and cobalt-60 radiation upon head and neck tumours. Oncology, 35: 253-257.

39. Sidell N, Altman A \& Haussler MR (1988). Effects of retinoic acid on the growth and phenotypic expression of several human neuroblastoma cell lines. Experimental Cell Research, 148: 21-30.

40. Sorenson CM \& Eastman A (1988). Mechanism of cis-diamminedichloro platinum (II)-induced cytotoxicity: role of G2 arrest and DNA double-strand breaks. Cancer Research, 48: 4484-4488.

41. Roberts JJ \& Fravel HNA (1978). The in- teraction of antitumor platinum compounds with cellular DNA in cultured cells and tissues: relationship to DNA cellular repair processes. Biochemie, 60: 869-876.

42. Roos IAG (1977). The interaction of antitumor platinum complex with DNA. Chemico-Biological Interactions, 16: 3946.

43. Zamble DB \& Lippard SJ (1995). Cisplatin and DNA repair in cancer chemotherapy. Trends in Biochemical Sciences, 20: 435439.

44. Zwelling LA, Michaels S, Schwartz $H$, Dobson PP \& Kohn KW (1981). DNA crosslinking as an indicator of sensitivity and resistance of mouse L1210 leukemia to cis-diamminedichloroplatinum (II) and L-phenylalanine mustard. Cancer Research, 41: 640-649.

45. Prasad KN, Gandreau D \& BrownJ (1981).
Binding of vitamin $\mathrm{E}$ in mammalian tumour cells in culture. Proceedings of the Society for Experimental Biology and Medicine, 166: 167-174.

46. Lupulescu A (1992). Ultrastructure and cell surface studies of cancer cells following vitamin $\mathrm{C}$ administration. Experimental Toxicology and Pathology, 44: 3-9.

47. Yasunaga $T$, Kato $H \&$ Ohogaki K (1982). Effect of vitamin $\mathrm{E}$ as an immunopotentiating agent for mice at optimum doses and its toxicity at high dosage. J ournal of Nutrition, 112: 1075-1084.

48. Yasunaga $T$, Ohogaki $K \&$ Inamoto $T$ (1982). Vitamin E and cancer treatment Experimental studies in mice. J ournal of J apanese Society for Cancer Therapy, 17: 2074-2083. 